\title{
Decrease of ARC protein expression in the striatum after tone fear conditioning
}

\author{
Redução proteica de $A R C$ no estriado após o \\ condicionamento de medo ao som
}

\section{Disminución protéica de ARC en el cuerpo estriado después del condicionamiento del miedo al tono}

\author{
Bruno Brito Antonio ${ }^{1}$, Kil Sun Lee ${ }^{2}$, Liz Paola Domingues ${ }^{3}$, Dimitri \\ Daldegan-Bueno ${ }^{4}$, Tatiana Lima Ferreira ${ }^{5}$, Juliana Carlota Kramer- \\ Soares $^{6}$, Maria Gabriela Menezes Oliveira ${ }^{7}$
}

\begin{abstract}
1.PhD. Departamento de Psicobiologia, Universidade Federal de São Paulo - UNIFESP, São Paulo-SP. Faculdade de Medicina do ABC - FMABC, Santo André-SP, Brasil.

2.PhD. Departamento de Bioquímica, Universidade Federal de São Paulo - UNIFESP, São Paulo-SP, Brasil. 3.MSc. Departamento de Psicobiologia, Universidade Federal de São Paulo - UNIFESP, São Paulo-SP, Brasil. 4.Bsc. Departamento de Psicobiologia, Universidade Federal de São Paulo - UNIFESP, São Paulo-SP, Brasil. 5.PhD. Centro de Matemática, Computação e Cognição, Universidade Federal do ABC - UFABC, São Bernardo do Campo-SP, Brasil.

6.PhD. Departamento de Psicobiologia, Universidade Federal de São Paulo - UNIFESP, Departamento de Psicologia, Universidade Ibirapuera - UNIB. São Paulo-SP, Brasil.
\end{abstract}

7.PhD. Departamento de Psicobiologia, Universidade Federal de São Paulo - UNIFESP, São Paulo-SP, Brasil.

\begin{abstract}
Resumo
Introdução. O envolvimento do sistema estriatal na aprendizagem S-R é geralmente baseado na plasticidade neural relacionada aos genes de expressão imediata (IEGs). Estudos anteriores também mostraram que o estriado dorsal desempenha um papel no condicionamento de medo do som (TFC). Objetivos. Dado que a expressão de IEGs no estriado dorsal está relacionada com a aprendizagem S-R, analisamos os eventos moleculares iniciais de consolidação no estriado medindo os níveis protéicos de EGR1, C-Fos e Arc, 30 e 90 minutos após o treino de TFC. Além disso, para minimizar uma possível interferência do hipocampo dorsal, a transmissão glutamatérgica foi interrompida durante o treino de condicionamento de medo usando a injeção de antagonista do receptor NMDA AP5 no hipocampo. Método. Ratos Wistar receberam AP5 ou injeção de solução salina no hipocampo cinco minutos antes de serem submetidos ao condicionamento de medo de som (pareamento som e choque) ou apenas o som. Resultados. Os animais que receberam pareamento som e choque nas patas apresentaram diminuição da proteína ARC 30 minutos após o treino quando comparados aos grupos controles. O grupo tratado com AP5, exposto à condição apenas de som, apresentou uma diminuição na proteína EGR 90 minutos após o treino quando comparada à solução salina e som. Não foram observadas diferenças nos níveis de proteína FOS. Conclusões. Nossos resultados sugerem que é possível que alguma interação entre estriado e hipocampo na experiência de processamento do som e que níveis reduzidos de ARC possam estar relacionados às características associativas desta tarefa pavloviana.
\end{abstract}

Unitermos. Memória; condicionamento de medo ao som; estriado; genes de expressão imediata

\footnotetext{
Abstract

Introduction. The involvement of the striatal system in S-R learning is usually based on neural plasticity related to immediate early-genes (IEGs). Previous studies also have shown that the dorsal striatum plays a role in tone fear conditioning (TFC). Objectives. Given that IEg expression in dorsal striatum supports S-R learning we analyzed early molecular consolidation events in the striatum by measuring the protein levels of the EGR1, C-Fos, and Arc in the striatum 30 and 90 minutes after the TFC training. Additionally, to minimize a dorsal hippocampal possible interference, glutamatergic transmission was disrupted during fear conditioning training using the NMDA receptor antagonist AP5 injection into hippocampus.
} 
Method. Wistar rats received AP5 or saline injection in the hippocampus five minutes before undergoing tone fear conditioning (tone and foot-shock pairings) or tone only. Results. Animals that received tone and footshock pairings presented a decrease in ARC protein 30 minutes after training when compared to the tone groups. AP5 treated group exposed to tone only condition presented a decrease in EGR protein 90 minutes after training when compared to the saline and tone. No differences were observed in FOS protein levels. Conclusions. Our results suggest that it is possible that some interaction between striatum and hippocampus in processing tone experience and that reduced levels of ARC could be related to the associative features of this pavlovian task.

Keywords. Memory; tone fear conditioning; striatum; immediate-early genes

\section{Resumen}

Introducción. La participación del sistema estriatal en el aprendizaje S-R se basa generalmente en la plasticidad neuronal relacionada con los genes de expression inmediata (IEG). Estudios anteriores también han demostrado que el cuerpo estriado dorsal cumple un papel en el condicionamiento del miedo al sonido (TFC). Objetivo. Dado que la expresión de IEG en el estriado dorsal está relacionada con el aprendizaje $S-R$, analizamos los eventos moleculares iniciales de consolidación en el cuerpo estriado midiendo los niveles de proteína de EGR1, CFos y Arc, 30 y 90 minutos después del entrenamiento de TFC. Además, para minimizar la posible interferencia del hipocampo dorsal, la transmisión glutamatérgica se interrumpió durante el entrenamiento de acondicionamiento del miedo utilizando la inyección de antagonista del receptor NMDA AP5 en el hipocampo. Método. Las ratas Wistar recibieron AP5 o una inyección de solución salina en el hipocampo cinco minutos antes de ser sometidas a un condicionamiento de miedo al sonido (emparejamiento de sonido y choque) o simplemente al sonido. Resultados. Los animales que recibieron sonido de emparejamiento y choque en las patas mostraron una disminución en la proteína ARC 30 minutos después del entrenamiento en comparación con los grupos de control. El grupo tratado con AP5, expuesto solo a la condición de sonido, mostró una disminución en la proteína EGR 90 minutos después del entrenamiento en comparación con la solución salina y el sonido. No se observaron diferencias en los niveles de proteína FOS. Conclusiones. Nuestros resultados sugieren que es posible que alguna interacción entre el cuerpo estriado y el hipocampo en la experiencia del procesamiento del sonido y que los niveles reducidos de ARC puedan estar relacionados con las características asociativas de esta tarea pavloviana.

Palabras clave. Memoria; condicionamiento del miedo al sonido; estriado; genes de expresión inmediata

Research developed at UNIFESP, São Paulo-SP, Brasil.

\section{INTRODUCTION}

There is extensive evidence of the involvement of the striatal system in learning and memory processes, mainly in the acquisition of habits ${ }^{1-4}$. These studies showed that response and cue learning are usually associated with the striatum. Damaging this structure in rats impairs learning in mazes that require a response solution ${ }^{1-4}$. It also impairs 
learning in the cue version of the water maze task, but not in the hidden platform spatial version ${ }^{3}$. These data suggest that the hippocampus and the dorsal striatum are parts of systems that differ in the type of memory they mediate. These striatal dependent tasks involve stimulus-response (SR) learning.

The involvement of the striatal system in S-R learning is usually based on neural plasticity related to immediate early-genes (IEGs), including IEG mRNA or protein products as C-Fos, EGR1 (Early growth response protein 1, also known as ZIF268, zinc finger protein 268) and ARC (Activityregulated cytoskeletal associated protein $)^{5-8}$. During memory acquisition and consolidation, intracellular molecular downstream events result in IEG induction, leading to the gene expression and protein synthesis required for memory formation. Several stimuli can induce the IEGs, such as neurotransmitters, peptides, and growth factors; their expression indicates a role in memory processing and behavior?.

The idea that the striatal system is also important in the fear conditioning paradigm, a form of CS-US associative learning, in addition to its already well-established role in S$\mathrm{R}$ learning, has become stronger ${ }^{2,10-12}$. This learning involves pairing an aversive stimulus (such as an electric shock - US) with a neutral stimulus (such as a tone - CS). After a stimuli association, the tone acquires the capacity to elicit behavioral and physiological fear responses ${ }^{10,11}$. However, the conditioned responses involve autonomic (e.g., heart rate 
and respiratory frequency) and somatomotor responses such as freezing, defined as complete absence of movement, except for that required for respiration ${ }^{13}$. Freezing time is used as an index of learning in classical conditioning paradigm, and previous studies in our laboratory showed that bilateral lesion of the dorsal striatum (DS) decreases the freezing response to a conditioned tone without interfering with the context fear conditioning $(\mathrm{CFC})^{10}$ and that the indirect amygdala striatum pathway is mediating this learning ${ }^{11}$. Moreover, medial striatum receives projections from auditory inputs. Later, other studies have corroborated the involvement of the striatum in tone fear conditioning ${ }^{12}$.

Given that IEG expression in dorsal striatum supports S-R learning we analyzed early molecular consolidation events in the striatum by measuring the protein levels of the EGR1, Fos, and Arc in the striatum after the TFC training.

In humans, a negative reaction to a sound, in which individuals experience intense emotional experiences and autonomic arousal when they are confronted with specific sounds can be consider misophonia, a condition that has been associated some psychological disorders, including anxiety and obsessive-compulsive disorders ${ }^{14}$. Some studies suggest that misophonia is associated with altered brain activity in the auditory cortex and corticostriatal areas ${ }^{15,16}$. Although this condition has not yet been observed directly in animal models, the study of tone fear conditioning could contribute to clarify our understanding of this pathology and 
can provide directions for future research into the mechanisms of misophonia.

\section{METHOD}

\section{Subjects}

Three-month-old male Wistar rats, weighing 300-400g, were bred and raised in animal facility of CEDEME (Centro de Desenvolvimento de Modelos Experimentais, from Universidade Federal de São Paulo - UNIFESP). The animals were housed in groups of five in standard polypropylene cages. The room was maintained at $23 \pm 2{ }^{\circ} \mathrm{C}$ with a $12 \mathrm{hr}$ light-dark cycle (lights on at 7a.m.). All procedures and experiments were conducted in the light phase. Rat chow and tap water were provided ad libitum. Methods and experiments were approved by the local Animal Care and Use Committee (\#0926/08), following international rules for animal use and care.

\section{Apparatus}

The conditioning chamber consists of a black acrylic box, measuring $22 \times 24 \times 35 \mathrm{~cm}$, with a transparent acrylic lid. The floor is made of parallel metallic rods, each $0.4 \mathrm{~cm}$ in diameter, $1.2 \mathrm{~cm}$ apart, and connected to a scrambler electric shock generator (AVS Projetos). For the tone conditioning test, a white cylindrical chamber (diameter $35 \mathrm{~cm}$, height $60 \mathrm{~cm}$ ) covered with a transparent acrylic lid was used. The two apparatus were cleaned with different substances and 
kept in different rooms. A tone $(60 \mathrm{~dB})$ was produced using a buzzer, placed outside the two apparatuses. Tone alone generates no alterations on rat behavior, just a subtle startle response first time it is presented.

\section{Procedures}

Conditioning Training. Training consists of place the animals individually in the conditioning chamber, where they remained for two min before any tone or tone-shock pairing was delivered. After this period, five tone or tone-footshock pairings were given. The tone (CS) sounded for 5 seconds $(60 \mathrm{~dB})$ and during the last second a foot shock (US; $0.6 \mathrm{~mA} / 1$

s) was delivered ending together with the tone. The interval between pairings was 30 seconds. These procedures were performed just as described previously in Ferreira et al studies $^{10,11}$.

After the pairings, the rats remained in the conditioning chamber for an additional minute and were then returned to their home cages. The control group animals, the SOUND group, were put in the conditioning chamber and exposed only to buzzer tone (no footshock was delivered, 60dB sound). For Experiment 1 animals were euthanized 30 (Experiment 1A) or 90min (Experiment 1B) after training.

For Experiment 2 animals were submitted to the test of CFC and TFC

CFC test: The contextual fear conditioning test was performed 24 hours after training on day 2 . The animals were 
again placed in the conditioning chamber, but neither the footshock nor the tone was delivered. Freezing time was measured continuously for 5 minutes by an experienced observer. The mean time per minute spent in freezing during the 5 min was used as a measure of contextual conditioning. Freezing was defined as complete immobility, including vibrissae movements and sniffing.

TFC test: The tone fear conditioning test was performed 48 hours after training on day 3 . The same animals were placed in the cylindrical chamber (a new environmental context) test for 6 minutes. At the end of the third minute, the tone $(60 \mathrm{~dB})$ alone was presented five times (without footshock at 30-seconds intervals). The freezing time was recorded during the first three minutes (before tone) and during the final three minutes (after/during tone). The mean time per minute spent in freezing after tone was used as a measure of tone conditioning, and before the tone as a measure of possible sensitization.

\section{Surgery and drug administration}

To minimize dorsal hippocampal interference in the striatum based learning, for half of the animals, the dorsal hippocampus glutamatergic system was disrupted before training with AP5, an NMDA antagonist receptor. Thus, events occurring in the striatum during/after fear conditioning would not be under basal hippocampal influence. The other half of animals received saline. 
Rats were anesthetized i.p. with $10 \mathrm{mg} / \mathrm{kg}$ of xylazine and $90 \mathrm{mg} / \mathrm{kg}$ of ketamine and placed in a stereotaxic frame. Stereotaxic guide-cannula was attached with the bregma and lambda used as reference points, on the same horizontal plane. An incision was made along the midline of the scalp, holes were drilled in the skull, and the cannula were placed bilaterally in the dorsal hippocampus. Stereotaxic coordinates were $3.5 \mathrm{~mm}$ posterior, $2.5 \mathrm{~mm}$ lateral from bregma, and $3.3 \mathrm{~mm}$ ventral from skull surface ${ }^{17}$. The tips of the infusion cannula protruded $1.0 \mathrm{~mm}$ beyond the guide cannula. The guide cannula was fixed to the skull by dental cement and micro screws, and a dummy cannula inserted into each guide cannula. Rats receive a pentabiotic (i.m.;

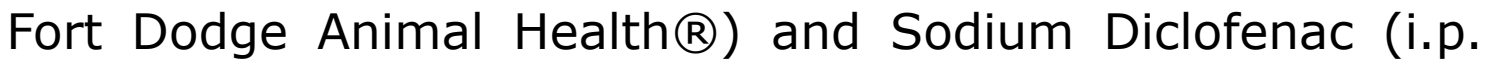

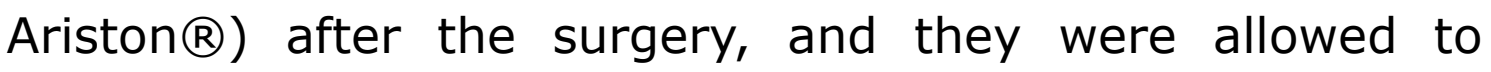
recover for seven days. From the third day post-surgery, the animals were separately manipulated for five minutes per day; then, the dummy cannula was replaced with a new one each day. After the surgery, the animals were individually housed in polypropylene plastic cages to prevent cannulae damage.

An NMDA receptor antagonist (d-AP5, Tocris $®)$, was dissolved in $0.9 \%$ saline (vehicle) and kept frozen until use. The dose used was $2.5 \mu \mathrm{g} / \mu \mathrm{l}$ and the total volume infused was $2 \mu \mathrm{l}$ at a rate of $0.4 \mu \mathrm{l} / \mathrm{min}$ for five minutes. The drug was kept at room temperature on the day of the experiment. The control animals received $2 \mu$ l of saline each side.

Solutions were injected bilaterally through 
microinjection needle (30 gauges), extended $1 \mathrm{~mm}$ beyond the tip of the guide cannula. Each microinjection needle was attached to a $10 \mu \mathrm{l}$ Hamilton microsyringe through polyethylene tubing (PE-10). Infusions were controlled by an infusion pump (Model Bi2000 - Insight Equipment $®$, São Paulo, Brazil), programmed to deliver the solution at a constant speed of $0.4 \mu \mathrm{l}$ per min. Rats were allowed to move freely during the drug administration, and after the microinjection, the needle was kept in place for two additional minutes to allow drug diffusion. The behavioral training began five minutes after this procedure.

\section{Euthanasia and Histology.}

After the behavioral test of Experiment 2, the rats were euthanized by a lethal dose of chloral hydrate, their brains were removed, frozen at $-80^{\circ} \mathrm{C}$ and sliced in coronal sections of $40 \mu \mathrm{m}$ in a cryostat. The sections were stained with cresyl violet and examined in a light microscope to determine the localization of the cannula track.

\section{Western Blot Analysis}

Striatum was homogenized in a lysis buffer (1\% Triton $\mathrm{X}-100 ; 0.5 \%$ sodium deoxicholate; $100 \mathrm{mM}$ Tris- $\mathrm{HCl}, \mathrm{pH} 8.3$; $150 \mathrm{mM} \mathrm{NaCl} ; 10 \mathrm{mM}$ EDTA; $0.1 \%$ SDS; $10 \%$ glycerol; protease cocktail inhibitor (Sigma)). The homogenate was incubated at room temperature for $10 \mathrm{~min}$ and then centrifuged for $5 \mathrm{~min}$ at $4^{\circ} \mathrm{C}, 7000 \times \mathrm{X}$. Supernatant was collected, total protein content was determined by Löwry 
method and kept frozen at $-80^{\circ} \mathrm{C}$ until utilization. Normalized

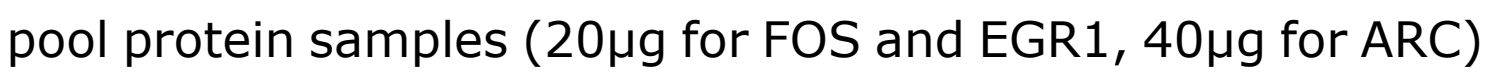
were loaded onto 10\% SDS-Polyacrylamide gels using an electrophoresis running buffer (25mM Tris, 192 mM glycine, $0,1 \%$ SDS, $\mathrm{pH}$ 8.6). Gels were equilibrated with transfer buffer (25 mM Tris, 192 mM glycina, 20\% methanol) before the protein was transferred to Nitrocelullose membranes. After transfer, the membranes were incubated in blocking solution (BSA 2\%, diluted in TBS-T) for one hour at room temperature and then incubated with primary antibody overnight at $4^{\circ} \mathrm{C}$, under constant movement. The following primary antibodies were diluted in blocking solution: FOS (1:1000, Abcam), EGR1 (1:1000, Abcam), ARC (1:1000, Abcam), $\beta$-actin (1:10000, Invitrogen). After the primary antibody incubation period, the membranes were washed three times for 5 minutes in TBS-T, before being incubated for 45 minutes in secondary antibody at room temperature (goat anti-rabbit 1:10000, Alexa 680 conjugated, Invitrogen; goat anti-mouse 1:10000, Alexa 680 conjugated, Invitrogen). Membranes were then washed five times for 5 minutes in TBS-T before scanning using an infrared image system Odyssey (Li-Cor Biosciences). After image digitalization, band densities were quantified using Odyssey software (Li-Cor Biosciences). Each group pool was loaded and ran 3-4 times. Expression fold changes were calculated using $\beta$-actin ratio. 


\section{Statistical Analysis}

Western blot data were first normalized with endogenous controls and then two-way ANOVA was applied, with TREATMENT (APV and saline -SAL) and GROUP (SOUND and PAIRED) as main factors. When applied, the analysis was followed by the Tukey post hoc test. For all tests, the level of significance was set at $p<0.05$.

Behavioral data were analyzed by two-way ANOVA with TREATMENT (APV and saline - SAL) and SESSION (training and test days) as main factors. TFC behavioral data were analyzed by two-way ANOVA with TREATMENT (APV and saline - SAL) and INTRASESSION (before and after tone) as main factors.

\section{RESULTS}

\section{Experiment 1A. IEGs expression in the striatum after $\mathbf{3 0}$ minutes of Fear Conditioning Training}

In the analysis performed in the striatum by western blot, no protein levels alterations were observed for EGR1 (Figure 1A). ANOVA revealed no differences for TREATMENT $\left(F_{(1,16)}=0.64 ; p=0.44\right)$, GROUP $\left(F_{(1,16)}=0.15 ; p=0.70\right)$ or the interaction TREATMENT X GROUP $\left(F_{(1,16)}=0.02 ; p=0.89\right)$. For ARC protein levels (Figure 1B), there was no difference for TREATMENT $\left(F_{(1,12)}=0.25 ; p=0.63\right)$, but there was a significant difference for GROUP $\left(F_{(1,12)}=5.01 ; p=0.045\right)$. PAIRED animals showed reduced levels of ARC when compared to SOUND animals. No TREATMENT $X$ GROUP interaction was detected $\left(F_{(1,12)}=1.54 ; p=0.24\right)$. For FOS 
protein expression (Fig. 1C), there were no differences for TREATMENT $\left(F_{(1,12)}=2.82 ; p=0.12\right)$, GROUP $\left(F_{(1,12)}=2.19\right.$; $\mathrm{p}=0.16)$ or the interaction TREATMENT $x$ GROUP $\left(F_{(1,12)}=0.44 ; p=0.52\right)$.

\section{Experiment 1B. IEGs expression in the striatum after 90 min of Fear Conditioning Training}

In Experiment $1 \mathrm{~B}$, the rats underwent the same experimental design described above, except that the structures were collected 90 minutes after TFC training.

In the analysis performed in the striatum by western blot, a reduced expression of EGR1 was observed (Figure 1D). TREATMENT $\times$ GROUP interaction $\left(F_{(1,16)}=8.35\right.$; $\mathrm{p}=0.010$ ) was significant. Post-hoc analysis showed that the SOUND-AP5 group presented a reduced expression of EGR1 protein compared to the SOUND-SAL group $(p=0.001)$. Interestingly, no reduced expression was observed in the PAIRED-AP5 group when compared to the PAIRED-SAL. There were no differences for TREATMENT $\left(F_{(1,16)}=0.62\right.$; $p=0.44)$ and $\operatorname{GROUP}\left(F_{(1,16)}=0.86 ; p=0.37\right)$ effects. For $A R C$ protein levels, no differences for TREATMENT $\left(F_{(1,12)}=0.55\right.$; $p=0.47)$, GROUP $\left(F_{(1,12)}=0.54 ; p=0.48\right)$ or the interaction TREATMENT $x$ GROUP $\left(\mathrm{F}_{(1,12)}=0.14 ; \mathrm{p}=0.72\right)$ were detected (Fig. 1E). Also no differences in protein expression of FOS were observed in the striatum (Fig. 1F), for TREATMENT $\left(F_{(1,12)}=0.06 ; p=0.80\right)$, GROUP $\left(F_{(1,12)}=0.44 ; p=0.52\right)$ or the interaction TREATMENT $x$ GROUP $\left(F_{(1,12)}=0.43 ; p=0.53\right)$ were detected. 
Figure 1. Protein expression of IEGs in the striatum 30minutes $(A, B$, and $C)$ and 90 minutes $(D, E$, and $F)$ after training. In panel $B$. There is a decreased expression of $A R C$ on PAIRED group when compared do SOUND group. In panel D. We also observed a decreased expression of EGR1 protein level in the SOUND-AP5 group No other differences were detected. $n$ in parenthesis represents the total number of pool replications. All graphs show mean $+\mathrm{SE}$. $(*=p<0.05)$.
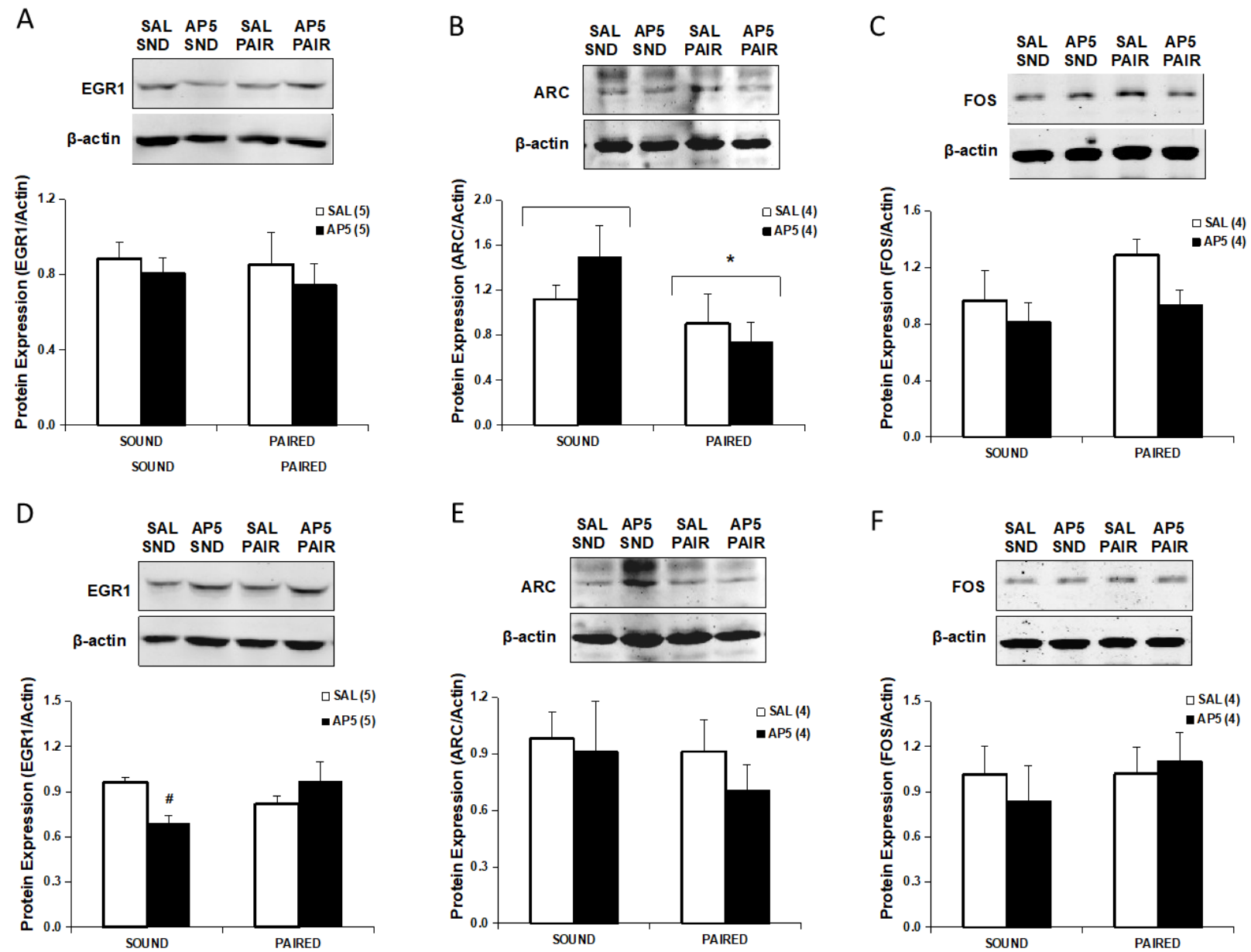

\section{Experiment 2. Effects of intrahippocampal AP5 administration on CFC and TFC}

The guide cannulae placement in the dorsal

hippocampus is represented in Figure 2 . The black circle represents the area where the cannulae tips were placed in each hemisphere. The tip of the cannulae reached the CA1 region of the dorsal hippocampus. The AP5 hippocampal administration impairs only CFC sparing TFC (Figure 3 ). The rats that received AP5 showed less freezing time in the CFC 
test when compared with saline-injected animals. Effects of TREATMENT $\quad\left(F_{(1,24)}=50.30 ; \quad p<0,0001\right), \quad$ SESSION $\left(F_{(1,24)}=85.71 ; \quad p<0,0001\right)$, and TREATMENT-SESSION interaction $\left(F_{(1,24)}=35,95 ; \quad p<0,0001\right)$ were significant (Figure 3A). TFC were conducted 24hs after the CFC. After three minutes, the same training tone was emitted. As Figure 3B shows, AP5 administration did not alter freezing time in TREATMENT $\left(F_{(1,24)}=2.95 ; p=0.10\right)$. We observed a higher freezing expression after tone in all animals (INTRASSESSION $\quad\left(F_{(2,48)}=128.13 ; \quad p<0.0001\right) . \quad$ No TREATMENT-INTRASESSION interaction was observed $\left(F_{(2,48)}=1,42 ; p=0.25\right)$.

Figure 2. Coronal schematic illustration of intrahippocampal administration of AP5. The black circles represent the general location of the tips of guide cannulae. Adapted from ${ }^{17}$

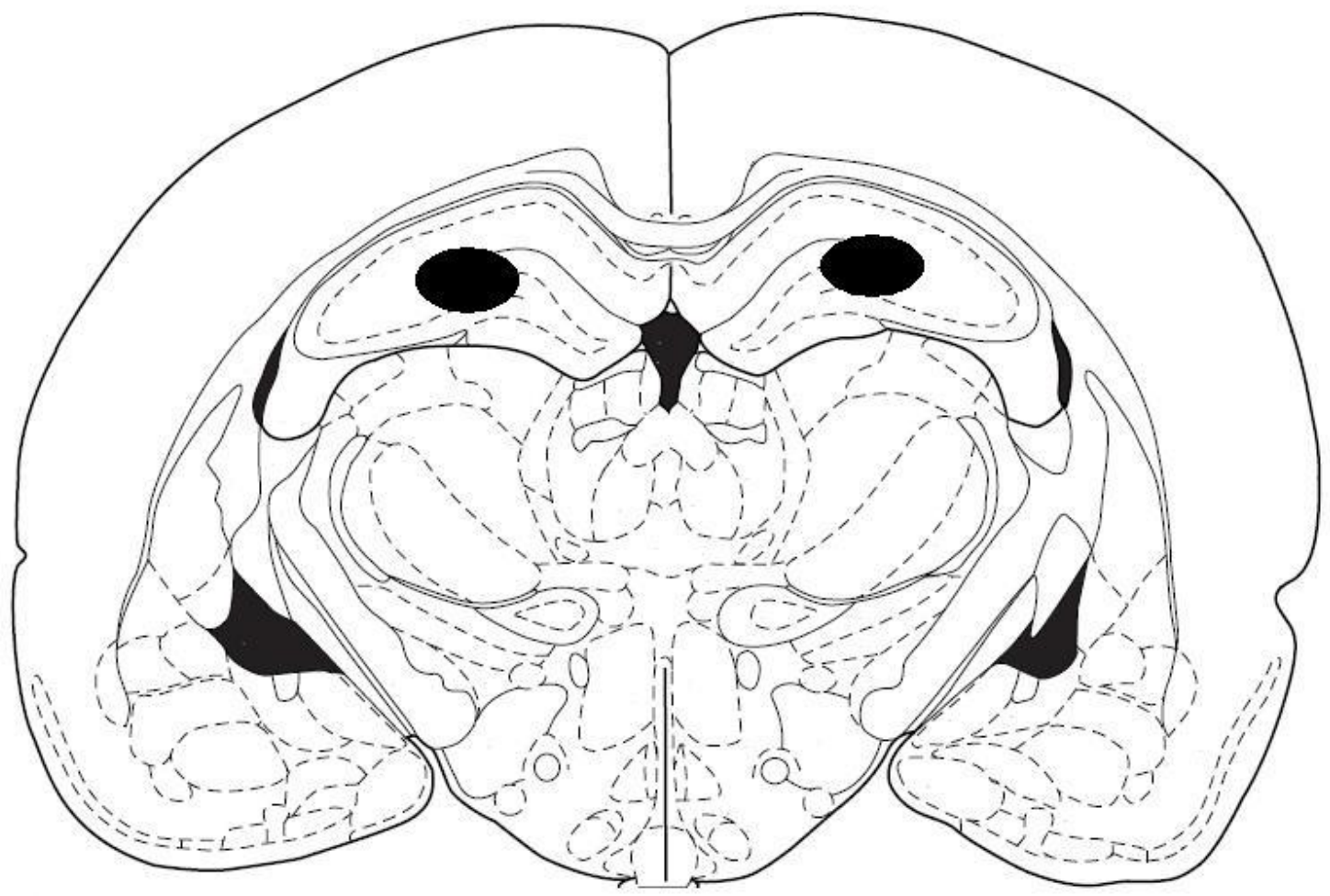


Figure 3. Intrahippocampal AP5 administration on rats before training of CFC and TFC on freezing behavior. A. Freezing time before training and test in CFC $* p<0.05$ as compared to saline. B. Freezing time before training and test TFC.
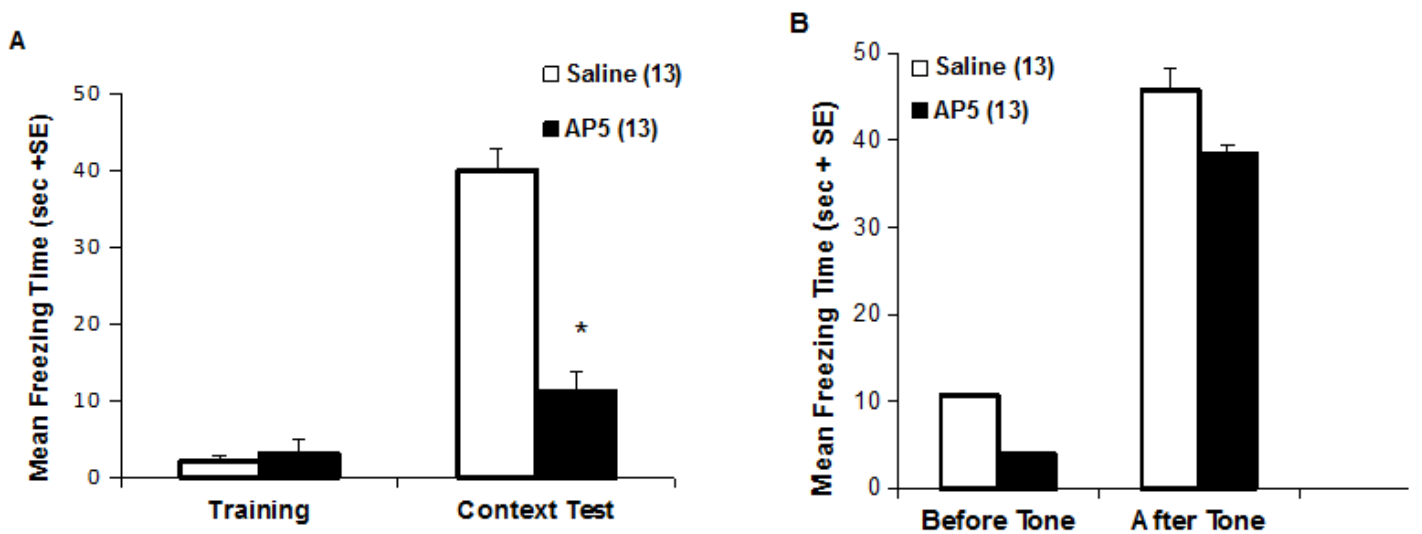

\section{DISCUSSION}

The main results of the present study are: 1 ) animals that received tone and footshock pairings presented a decrease in ARC protein 30 minutes after training when compared to the tone groups. 2) AP5 treated group exposed to tone only condition presented a decrease in EGR protein 90 minutes after training when compared to the respective control group, but spared TFC conditioned freezing response.

The present study showed that 30min after the training of TFC there was a reduction on the Arc protein expression in the striatum. The effect direction was the opposite of expected by the hypothesis generated in this study. If the involvement of the striatum in TFC was like the one observed in S-R tasks ${ }^{5-8}$ we expected an increased expression of IEGs. Although the result was unexpected, the two PAIRED groups exhibited this similar profile, reinforcing the idea that some aspect of the TFC training led to a decrease of ARC protein 
expression when compared to animals that were exposed to the training environment and the tones. One of this groups had the hippocampal glutamatergic systems disrupted through AP5 administration. This was done to minimize any possible dorsal hippocampal interference on striatal IEGs expression, as there is evidence of cooperative and competitive mechanism between the hippocampus and dorsal striatum. For instance, the overexpression of CAMP response element-binding protein (CREB) in the dorsolateral striatum improves long-term memory in CFC ${ }^{18}$. Blocking the hippocampal NMDA transmission do not interfere with the conditioned response on TFC but interfered with contextual fear conditioned response, what replicate others from literature ${ }^{19,20}$. Because the decrease of ARC occurred in PAIRED groups regardless of the administration of AP5 or saline administration, the observed effect in both groups seems to be a consequence of the training procedures and not the hippocampus manipulation.

Given that it has been shown that the striatum is involved in TFC ${ }^{10-12}$, the decreased expression of ARC after a CS-US associative learning shows that tone fear conditioning induces a different profile of genes expression in the striatum from the ones observed in the literature, where increased expression of IEGs has been observed, most of them using appetitive tasks ${ }^{6,7}$. To our knowledge, this is the first study to have observed decreased IEG expression in the striatum after TFC. Thus, is possible that Pavlovian and instrumental conditioning differ in the way the striatum mobilizes IEG 
expression. In an S-R learning task in a plus maze, an increase in $c$-fos in the dorsal striatum was observed. However, this same study did not find differences in Zif-268 (i.e. EGR1) expression7. Other work observed an increased ARC protein levels in the striatum after a discrimination task in a plus maze ${ }^{6}$. The subregions of dorsal striatum also take part in drug-seeking neural plasticity of behavior. In cocaine self-administration protocols, ARC expression is decreased in dorsal medial striatum (DMS) but not in dorsal lateral striatum (DLS) in addiction-vulnerable animals ${ }^{21,22}$. In these studies, gene and protein expressions were evaluated after an extensive behavioral protocol (self-administration training, progressive ratio, extinction, and finally, cue induced-reinstatement of lever pressing). Despite the typical instrumental learning used for an extended period of this task acquisition, these animals were exposed to a CS-US classical conditioning protocol, in which a sound signalized the cocaine availability. After that, long extinction training was conducted, and IEGs were analyzed 24 hours after the test of cue induced-reinstatement of lever press in a protocol very similar to test a CS-US association (typical pavlovian conditioning). Specifically, the rats that showed more associative features related to drug-seeking (addictionvulnerable animals) showed reduced ARC protein levels. In this circumstance, our results are similar to these works, showing decreased IEGS expression in animals submitted to a CS-US association. Again, the apparent divergence between results in the literature and those of our study in 
respect of IEG expression in the striatum can be explained by the type of task that was used (instrumental x pavlovian). Additionally, appetitive, and aversive tasks seem to activate independent pathways within the striatum ${ }^{23}$, which can lead to distinct pattern expressions. However, it was observed the increase of ARC in ventral, but not in dorsal striatum after inhibitory avoidance task, a complex paradigm that require both instrumental and pavlovian learning ${ }^{24}$. It is important to note that we did not investigate striatum subregions (the dorsal and ventral striatum). It is well-known that the ventral striatum is associated with the hippocampus and has a role in CFC. Our results show a decrease of ARC expression in the PAIRED groups even when analyzing the entire striatum, suggesting that alterations on ARC expressions are involved in memory consolidation of TFC also this region.

Besides the ARC protein differential expression, the striatum is critical for S-R learning ${ }^{1-4}$, but it does not seem to be critical for TFC for the acquisition of the association between CS and US, once lesions in the striatum after training did not alter heart rate pattern ${ }^{25}$. In the same way, lesions in the striatum impaired the acquisition of conditioned eyelid response in classical conditioning, but no effect was observed in the heart rate conditioned response ${ }^{26}$. However, the striatum has a critical role when the conditioning is evaluated by the conditioned somatomotor response ${ }^{10,11}$. Thus, we speculate that the organization of the somatic-response aspect at the conditioned response can be related to a decreased expression of IEGs in the striatum. 
In experiment $1 \mathrm{~B}$ we observed no EGR1 alteration when comparing GROUPS, but we show a decreased EGR levels 90min after the animals received TONE-AP5. Taken together, these results suggest that hippocampal NMDA activity, which is important for contextual learning ${ }^{19,20}$, can still have some influence on the acquisition/consolidation of fear conditioning and even affect striatal function. In addition, it has been proposed that hippocampus and striatum may potentially interact and that, depending on the learning situation, this interaction may be cooperative or competitive with each other during learning 27,28 .

\section{CONCLUSION}

Overall, we observed that after short periods of TFC training, there is a reduction in IEGs. Our results also suggest that it is possible that some interaction between striatum and hippocampus in processing tone experience and that reduced levels of ARC could be related to the associative features of this pavlovian task.

\section{ACKNOWLEDGMENT}

The authors would like to thank José Bernardo Costa for technical assistance during the behavior experiments.

This study was financially supported by grant \#2008/04305-2, São Paulo Research Foundation (FAPESP), the Research Incentive Fund Association (AFIP), the 
Coordination for the Improvement of Higher Education

Personnel (CAPES) and the National Council of Scientific and Technological Development (CNPq). The funders had no role in study design, data collection and analysis, decision to publish, or preparation of the manuscript.

\section{REFERENCES}

1.Chang Q, Gold PE. Inactivation of dorsolateral striatum impairs acquisition of response learning in cue-deficient, but not cue-available, conditions. Behav Neurosci 2004;118:383-8. http://dx.doi.org/10.1037/0735-7044.118.2.383

2. Devan BD, Hong NS, McDonald RJ. Parallel associative processing in the dorsal striatum: segregation of stimulus-response and cognitive control subregions. Neurobiol Learn Mem 2011;96:95-120. http://dx.doi.org/10.1016/j.nlm.2011.06.002

3. Miyoshi E, Wietzikoski EC, Bortolanza M, Boschen SL, Canteras NS, Izquierdo I, et al. Both the dorsal hippocampus and the dorsolateral striatum are needed for rat navigation in the Morris water maze. Behav Brain Res 2012;226:171-8. http://dx.doi.org/10.1016/j.bbr.2011.09.011

4.Soares JCK, Oliveira MGM, Ferreira TL. Inactivation of muscarinic receptors impairs place and response learning: Implications for multiple memory systems. Neuropharmacology 2013;73:320-6. http://dx.doi.org/10.1016/j.neuropharm.2013.06.009

5. Hernandez PJ, Schiltz CA, Kelley AE. Dynamic shifts in corticostriatal expression patterns of the immediate early genes Homer 1a and Zif268 during early and late phases of instrumental training. Learn Mem 2006;13:599-608. http://dx.doi.org/10.1101/Im.335006

6.Daberkow DP, Riedy MD, Kesner RP, Keefe KA. Arc mRNA induction in striatal efferent neurons associated with response learning. Eur J Neurosci 2007;26:228-41. http://dx.doi.org/10.1111/j.14609568.2007.05630.x

7.Gill KM, Bernstein IL, Mizumori SJ. Immediate early gene activation in hippocampus and dorsal striatum: effects of explicit place and response training. Neurobiol Learn Mem 2007;87:583-96. http://dx.doi.org/10.1016/j.nlm.2006.12.011

8. Brightwell JJ, Smith CA, Neve RL, Colombo PJ. Transfection of mutant CREB in the striatum, but not the hippocampus, impairs long-term memory for response learning. Neurobiol Learn Mem 2008;89:27-35. http://dx.doi.org/10.1016/j.nlm.2007.09.004

9. Okuno $\mathrm{H}$. Regulation and function of immediate-early genes in the brain: Beyond neuronal activity markers. Neurosci Res 2011;69:17586. http://dx.doi.org/10.1016/j.neures.2010.12.007 
10.Ferreira TL, Moreira KM, Ikeda DC, Bueno OF, Oliveira MG. Effects of dorsal striatum lesions in tone fear conditioning and contextual fear conditioning. Brain Res 2003;987:17-24. http://dx.doi.org/10.1016/s0006-8993(03)03217-7

11.Ferreira TL, Shammah-Lagnado SJ, Bueno OF, Moreira KM, Fornari RV, Oliveira MG. The indirect amygdala-dorsal striatum pathway mediates conditioned freezing: insights on emotional memory networks. Neuroscience 2008;153:84-94. http://dx.doi.org/10.1016/j.neuroscience.2008.02.013

12. Kishioka A, Uemura T, Fukushima F, Mishina M. Consolidation of auditory fear memories formed by weak unconditioned stimuli requires NMDA receptor activation and de novo protein synthesis in the striatum. Mol Brain 2013;15:6-17. http://dx.doi.org/10.1186/17566606-6-17

13.LeDoux JE. Evolution of human emotion: a view through fear. Prog Brain Res 2012;195:431-42. http://dx.doi.org/10.1016/B978-0-44453860-4.00021-0

14.Cusack SE, Cash TV, Vrana SR. An examination of the relationship between misophonia, anxiety sensitivity, and obsessive-compulsive symptoms. J Obsessive Compuls Relat Disord 2018;18:67-72. https://dx.doi.org/10.1016/j.jocrd.2018.06.004

15. Martino D, Hedderly T. Tics and stereotypies: A comparative clinical review. Parkinsonism Relat Disord 2019;59:117-24. http://dx.doi.org/10.1016/j.parkreldis.2019.02.005

16.Schröder A, van Wingen G, Eijsker N, San Giorgi R, Vulink NC, Turbyne $\mathrm{C}$, et al. Misophonia is associated with altered brain activity in the auditory cortex and salience network. Sci Rep 2019;9:7542. http://dx.doi.org/10.1038/s41598-019-44084-8

17.Paxinos G, Watson C. The Rat Brain in Stereotaxic Coordinates. San Diego: Academic Press, 2005.

18. Kathirvelu B, Colombo PJ. Effects of lentivirus-mediated CREB expression in the dorsolateral striatum: memory enhancement and evidence for competitive and cooperative interactions with the hippocampus. Hippocampus 2013;23:1066-74. http://dx.doi.org/10.1002/hipo.22188

19.Schenberg $E E$, Oliveira MG. Effects of pre- or post-training dorsal hippocampus d-AP5 injection on fear conditioning to tone, background and foreground context. Hippocampus 2008;18:1089-93. http://dx.doi.org/10.1002/hipo.20475

20.de Oliveira Coelho CA, Ferreira TL, Soares JC, Oliveira MG. Hippocampal NMDA receptor blockade impairs CREB phosphorylation in amygdala after contextual fear conditioning. Hippocampus 2013;23:545-51. http://dx.doi.org/10.1002/hipo.22118

21.Brown AL, Flynn JR, Smith DW, Dayas CV. Down-regulated striatal gene expression for synaptic plasticity-associated proteins in addiction and relapse vulnerable animals. Int J Neuropsychopharmacol 2011;14:1099-110. http://dx.doi.org/10.1017/S1461145710001367

22.Quinn RK, Brown AL, Goldie BJ, Levi EM, Dickson PW, Smith DW, et al. Distinct miRNA expression in dorsal striatal subregions is associated 
with risk for addiction in rats. Transl Psychiatr 2015;5:e503. http://dx.doi.org/10.1038/tp.2014.144

23. Hikida T, Kimura K, Wada N, Funabiki K, Nakanishi S. Distinct roles of synaptic transmission in direct and indirect striatal pathways to reward and aversive behavior. Neuron 2010;66:896-907. http://dx.doi.org/10.1016/j.neuron.2010.05.011

24.González-Franco DA, Ramírez-Amaya V, Joseph-Bravo P, PradoAlcalá RA, Quirarte GL. Differential Arc protein expression in dorsal and ventral striatum after moderate and intense inhibitory avoidance training. Neurobiol Learn Mem 2017;140:17-26. http://dx.doi.org/10.1016/j.nlm.2017.02.001

25. Reyes Vazquez C, Zarco-Coronado I, Brust-Carmona H. Effects of intracaudate microinjections of 6-hydroxydopamine upon the suppression of lever pressing and upon passive avoidance conditioning in cats. Pharmacol Biochem Behav 1978;9:747-51. http://dx.doi.org/10.1016/0091-3057(78)90351-9

26. Powell DA, Mankowski D, Buchanan S. Concomitant heart rate and corneoretinal potential conditioning in the rabbit (Oryctolagus cuniculus): effects of caudate lesions. Physiol Behav 1978;20:143-50. http://dx.doi.org/10.1016/0031-9384(78)90066-5

27.Mizumori SJ, Yeshenko O, Gill KM, Davis DM. Parallel processing across neural systems: implications for a multiple memory system hypothesis. Neurobiol Learn Mem 2004;82:278-98. http://dx.doi.org/10.1016/j.nlm.2004.07.007

28.Packard MG, Goodman J. Factors that influence the relative use of multiple memory systems. Hippocampus 2013;23:1044-52. http://dx.doi.org/10.1002/hipo.22178 